\title{
The Diversity of the Mitochondrial Outer Membrane Protein Import Channels: Emerging Targets for Modulation
}

\author{
Monika Mazur, Hanna Kmita (D) and Małgorzata Wojtkowska *(D) \\ Institute of Molecular Biology and Biotechnology, Faculty of Biology, Adam Mickiewicz University, \\ 61-614 Poznan, Poland; monika.antoniewicz@gmail.com (M.M.); kmita@amu.edu.pl (H.K.) \\ * Correspondence: malgorzata.wojtkowska@amu.edu.pl; Tel.: +48-61929-59-02
}

check for updates

Citation: Mazur, M.; Kmita, H.; Wojtkowska, M. The Diversity of the Mitochondrial Outer Membrane Protein Import Channels: Emerging Targets for Modulation. Molecules 2021, 26, 4087. https://doi.org/ $10.3390 /$ molecules 26134087

Academic Editor: Yukio Yoneda

Received: 4 June 2021

Accepted: 1 July 2021

Published: 4 July 2021

Publisher's Note: MDPI stays neutral with regard to jurisdictional claims in published maps and institutional affiliations.

Copyright: (c) 2021 by the authors. Licensee MDPI, Basel, Switzerland. This article is an open access article distributed under the terms and conditions of the Creative Commons Attribution (CC BY) license (https:// creativecommons.org/licenses/by/ $4.0 /)$.

\begin{abstract}
The functioning of mitochondria and their biogenesis are largely based on the proper function of the mitochondrial outer membrane channels, which selectively recognise and import proteins but also transport a wide range of other molecules, including metabolites, inorganic ions and nucleic acids. To date, nine channels have been identified in the mitochondrial outer membrane of which at least half represent the mitochondrial protein import apparatus. When compared to the mitochondrial inner membrane, the presented channels are mostly constitutively open and consequently may participate in transport of different molecules and contribute to relevant changes in the outer membrane permeability based on the channel conductance. In this review, we focus on the channel structure, properties and transported molecules as well as aspects important to their modulation. This information could be used for future studies of the cellular processes mediated by these channels, mitochondrial functioning and therapies for mitochondria-linked diseases.
\end{abstract}

Keywords: mitochondria; import channel; TOM; TOB/SAM; Tom40; Tob55/Sam50; Mdm10; MIM; MAC

\section{Introduction}

According to the endosymbiotic theory, mitochondria arose from prokaryotes through (endo)symbiosis. These double-membrane organelles have retained the oxidative phosphorylation system to synthesize ATP. This is the best-known function of mitochondria, which makes them unique and crucial for cells. However, in the course of evolution, nearly all ancestral genes were transferred into the nucleus. As a result, most mitochondrial proteins are synthesized in the cytosol and must be delivered to their correct mitochondrial destination $[1,2]$. Thus, protein import into the mitochondria seems to be additional evidence for the single origin of these organelles.

Since the last years, studies of protein import into mitochondria have revealed many aspects concerning the composition and function of the protein import machinery, which consists of protein import complexes with the main module working as an import channel that allows protein transfer across and into both mitochondrial membranes. The first barrier for incoming proteins is the mitochondrial outer membrane, which has approximately 200 proteins, of which some display channel activity [3]. To date, nine different channelforming proteins responsible for the transport of metabolites, inorganic ions and proteins have been distinguished in the outer membrane [4]. Some of these proteins have a $\beta$-barrel structure and include Tom40, Tob55/Sam50, the voltage-dependent anion-selective channel (VDAC) and Mdm10, mitochondrial apoptosis channel (MAC) while those with other types of structure include Mim1, Ayr1, OMC7 and OMC8 [5]. The protein channels described in this review, except of the MAC, are constitutively open and do not need activators to regulate its opening. This phenomenon makes them different than channels located within the inner mitochondria membrane.

In this review, we focus on the outer membrane protein import channels characterized as single modules and as subunits of the native complexes. We present current data about their structure, regulation and variety of transported molecules. Such knowledge is crucial 
for development of the channels' modulators which could prove effective in correcting mitochondrial processes that in turn may constitute an important therapeutic approach in disease treatment.

\section{Overview of the Mitochondrial Protein Import Machinery}

The successful import of precursor proteins into their destinations in mitochondria primarily depends on the mitochondrial membrane complexes and specific signals localised within the incoming precursor proteins. The membrane import complexes-known as translocases-are composed of receptor subunits that recognise incoming precursor proteins, proteins that form channels for transport across membranes or insertion into membranes and protein subunits that modulate the activity and stability of complexes. In the mitochondrial outer membrane, four complexes have been identified (Figure 1): translocase of the outer mitochondrial membrane (TOM) [6,7], topogenesis of the mitochondrial outer membrane $\beta$-barrel proteins/sorting and assembly machinery (TOB/SAM) [8-11], mitochondrial import complex (MIM) $[12,13]$ and endoplasmic reticulum-mitochondria encounter structure (ERMES) [14]. The TOM complex recognises, translocates and segregates most of the precursor proteins delivered to different mitochondrial locations. The TOB/SAM complex inserts into the outer membrane proteins of the $\beta$-barrel structure displayed by proteins forming channels, such as Tom40, Tob55/Sam50, mitochondrial distribution and morphology protein 10 (Mdm10; part of the ERMES complex) and mitochondrial porin (a VDAC responsible for metabolite and inorganic ion transport in and out of the mitochondria) [2]. The MIM complex inserts the $\alpha$ helical outer membrane proteins, which are imported independently of the TOM complex [12].

Precursor proteins destined for the intermembrane space (IMS) are assisted by the mitochondrial intermembrane space and assembly (MIA) complex [15]. Other precursors are transported or inserted into the inner membrane by two complexes (i.e., TIM23 [15,16] and TIM22 [17,18]). The TIM23 complex primarily performs import into the mitochondrial matrix, whereas the TIM22 complex performs insertion into the inner membranes of carrier proteins (for more details on the import across and into the inner membrane, see the following reviews: $[19,20]$ ) (Figure 1).

\section{Protein Import across and into the Mitochondrial Outer Membrane}

The most widely used model organism in studies on mitochondria protein import machinery is the yeast Saccharomyces cerevisiae, which is also used as a reference for comparative studies on other eukaryotic organisms, including plants and animals [2,21]. As previously mentioned, the TOM complex receptors specifically recognise the incoming precursor proteins. Tom 20 binds to the hydrophobic surface of the cleavable amphipathic presequence and initiates contact with the next receptor (i.e., Tom22 protein via its positively charged surface). In the case of non-cleavable hydrophobic precursors serving as carrier proteins with the inner membrane as the destination, the Tom70 receptor is engaged. Crossing of the outer membrane is performed by channel-forming Tom 40 protein and small Tom subunits (e.g., Tom5, Tom6 and Tom7) that stabilize the complex and contribute to the proper assembly of its subunits [22]. From this entry point, import pathways diverge into different directions depending on the final destination of the protein [2] (Figure 1). After crossing through the channel formed by Tom 40 , proteins that adopted a $\beta$-barrel structure are bound to small TIM proteins in the IMS (i.e., Tim9 and Tim10) $[23,24]$ and delivered to the TOB/SAM complex. The TOB/SAM complex consists of two peripheral membrane proteins exposed to the cytosol, namely Tob38 (also known as Sam35) and Tob37 (also known as Sam37/Mas37), as well as the channel-forming protein Tob55/Sam50 [25-29]. Thus, the TOB/SAM complex recognises $\beta$-barrel proteins and assists their membrane insertion and assembly $[3,30]$. Available data concerning the mammalian TOB/SAM complex indicate the presence of weakly conserved homologues of Tob37 and Tob38, known as metaxin 1 (Mtx1) and metaxin 2 (Mtx2), respectively [30-32]. The TOB/SAM complex of the slime mould Dictyostelium discoideum includes Tob55/Sam50 and one metaxin homolog [33-35]. 
It has also been proven that $\beta$-barrel proteins interact with the mitochondrial contact site and cristae organising system (MICOS) complex, which maintains the characteristic pleated structure of the mitochondrial inner membrane [36,37]. One of the MICOS complex subunits, Mic60/mitofilin, stimulates $\beta$-barrel protein transfer from the TOM complex to the TOB/SAM complex [38]. The outer membrane proteins anchored by one or more $\alpha$-helical transmembrane segments are mostly inserted by the MIM complex, which consists of Mim1 and Mim2 protein subunits [4]. Additionally, the MIM complex cooperates with the protein Mdm10, which is part of the ERMES complex [14].

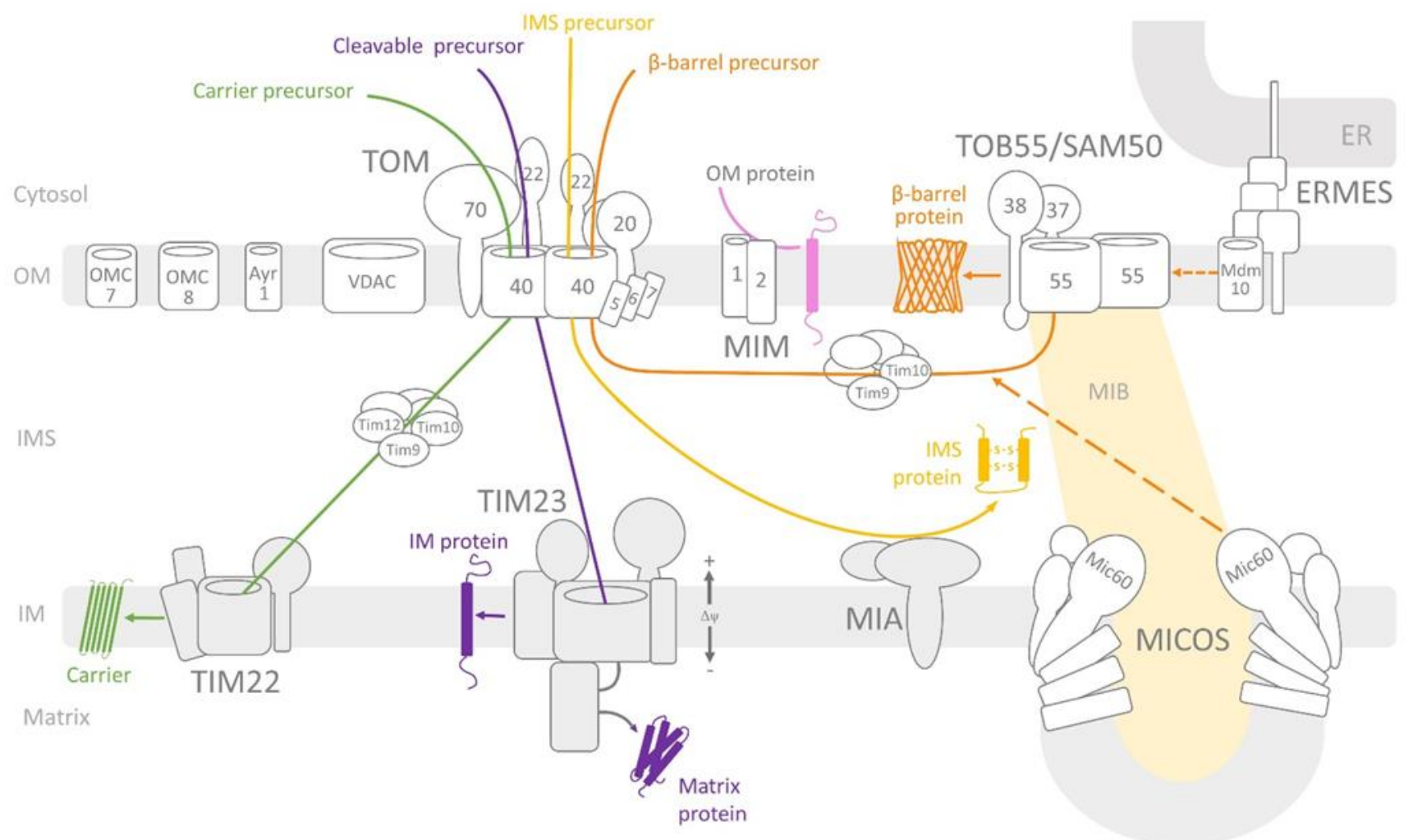

Figure 1. Overview of protein import into mitochondria. The TOM complex recognises most of the mitochondrial preproteins via its receptors (i.e., Tom20, Tom 22 and Tom70) and imports across the outer membrane through the Tom40 channel (dimer). Small TOM subunits (i.e., Tom5, Tom6 and Tom7) stabilise the TOM complex. $\beta$-barrel precursors (i.e., Tom40, Tob55/Sam50, VDAC and Mdm10) are inserted into the outer membrane by the TOB/SAM complex, which consists of the protein channel Tob55/Sam50 (dimer) and receptors Tob38 and Tob37. The mitochondrial contact site and cristae organising system (MICOS) complex supports the insertion of the $\beta$-barrel proteins into the OM. The dynamic structure of TOB/SAM and MICOS is called mitochondrial intermembrane space bridging (MIB). $\alpha$-helical precursors are inserted into the OM by the MIM complex (Mim1 and Mim2). The ERMES complex links the mitochondria and endoplasmic reticulum (ER) and supports the topogenesis of the mitochondrial outer membrane $\beta$-barrel proteins/sorting and assembly machinery (TOB/SAM) complex. The precursor targeted into the intermembrane space engages the MIA complex. TIM23 is responsible for import across the IM or into the mitochondrial matrix. TIM22 inserts carrier proteins into the IM. Voltage-dependent anion-selective channel (VDAC) is responsible for metabolite transport. Ayr1, OMC7 and OMC8 are the channels of unknown substrates. OM—outer membrane; IM-inner membrane; IMS—intermembrane space; ER-endoplasmic reticulum.

\section{Structure and Properties of the Outer Membrane Protein Import Channels}

\subsection{Tom40 Channel}

Tom40 is the central and channel-forming subunit of the TOM complex [3,21]. A wide range of important studies on protein import into mitochondria have shown that Tom 40 is not only the entry gate for most mitochondrial precursor proteins delivered from the 
cytosol to various sub-mitochondrial locations [39-41] since it also works as a decisive general selectivity filter in the uptake of newly synthesized mitochondrial proteins [42,43]. Moreover, it was also proposed that the TOM complex can act as an insertase mediating lateral release of the membrane imported proteins into the outer membrane [44].

As a protein with a $\beta$-barrel structure, Tom40 [45] contains 19 antiparallel $\beta$-strands that enable channel formation [10]. The copy number of Tom 40 proteins in yeasts cells was estimated at $\sim 45,000$ copies per cell [46]. The structure of the TOM complex and its electrophysiological properties has been studied for the last three decades. In the previous study $[47,48]$, two kinds of the TOM complex were observed: three-channel complex representing trimeric form of Tom 40 and two-channel complex representing dimeric form of Tom40. It was showed that the two-channel complex consisted of two Tom 40 and small Tom subunits but did not contain Tom22. It was concluded that the two-channel complex dimmer functioned as a premature complex [49] whereas the mature TOM complex dynamically exchanges with the two channel one providing an assembly platform for the integration of new subunits. Recent years have brought the intensive development of microscopy techniques that have facilitated the study of specifically labelled active membrane protein complexes in the native membrane. The structure of the studied complexes is based on electron cryo-tomography (cryo-ET) presenting the surface and internal conformation at nanometre resolution [50]. The higher resolution of cryo-EM microscopy revealed a stable dimeric form of the TOM complex for Neurospora crassa at a resolution of $0.68 \mathrm{~nm}$ [51], with resolutions of $0.38 \mathrm{~nm}$ for S. cerevisiae [52] and $0.34 \mathrm{~nm}$ for humans [53] and a resolution of $0.41 \mathrm{~nm}$ for its tetrameric form $[50,54]$. According to the obtained TOM complex model, two Tom40 subunits form two pores for protein translocation across the membrane. Each Tom40 is connected by two Tom 22 receptors and one phosphatidylcholine (PC) molecule. The latter is the most abundant phospholipid in the mitochondrial outer membranes and functions as a player in protein import into mitochondria [55]. Each Tom 40 is surrounded by small Tom subunits (i.e., Tom5, Tom6 and Tom7), with Tom5 being situated at the distal end of the Tom 40 dimer and Tom 6 and Tom7 being located on opposite sides across the channel pore. A study on the human TOM complex [53] revealed a negative interior of the pore and positive regions at its periphery. Notably, the dimeric form of the TOM complex may associate to form a tetramer. The molecular weight of the human TOM complex was estimated at $150 \mathrm{kD}$, which is comparable to the size of the TOM complexes of $S$. cerevisiae $[52,54]$ and $N$. crassa $[51,56]$. This is congruent with a previous study on the monomeric forms of the N. crassa [47] and S. cerevisiae TOM complexes [40], which were obtained via the circular dichroism method. These TOM complexes were estimated at a resolution of $0.68 \mathrm{~nm}$ and showed two pores in the dimer, each with a shortest diameter of $1.1 \mathrm{~nm}$ and longest diameter of $3.2 \mathrm{~nm}$.

The structure of the Tom 40 pore has been reported by various groups [52,54] and resulted in similar models with some differences. In contrast to the Tom 40 structure of yeast, the human Tom 40 structure does not contain an $\alpha$-helical segment preceding the internal helix at the $\mathrm{N}$ terminus and also lacks an additional C-terminal $\alpha$-helix at the end of 19th $\beta$-strand. Studies of the purified Tom 40 of Candida glabrata [57] revealed that the conserved 51 amino acids at the $\mathrm{N}$ terminus of the Tom 40 sequence, the 15 amino acids at its $C$ terminus and the interaction with a pre-sequence of the precursor protein were not crucial for channel formation. These results demonstrated that all studied Tom 40 constructs formed channels of different conductance. Each of the expressed proteins interacted with a pre-sequence peptide in the concentration dependent manner although the interaction with the conserved N-terminal Tom 40 domain was not required. This study showed that Tom 40 dimers were functional and their distinct conformations were regulated by binding of the substrate. For yeast and human Tom40, the $\alpha$-helical domain that traverses the channel pore and extends into IMS plays a crucial function in import across the Tom 40 channel. It was noted that residues T82, N79, P80, H87 and Q97 in the internal portion of Tom40 form hydrogen bonds with R195, T200, K253, T264 and Q353 in $\beta$-strands 7, 8, 11, 12 and 19 of 
Tom40, respectively. Despite it being partially unfolded, the presence of the internal helix limits the diameter of Tom 40 enough for the translocation of the precursor protein.

As previously mentioned, the activity of the Tom 40 channel could be stimulated by PC, which contains the positively charged choline group extending into the IMS. This was suggested to have a possible function in the translocation process [55]. Electrophysiological studies were performed on purified TOM complex and purified Tom40. The Tom 40 channel shows a preference for cations: $P_{K^{+}}{ }^{+} P_{C l}{ }^{-}=8: 1$ with a reversal potential of $40 \mathrm{mV}$ (planar lipid bilayer technique performed on $S$. cerevisiae Tom40, according to [40]) (Table 1). In an experiment performed by [58], S. cerevisiae and N. crassa Tom40 were expressed in Escherichia coli cells and renatured. The electrophysiology measurements in planar lipid bilayers at a symmetrical concentration of $250 \mathrm{mM} \mathrm{KCl}$ were indistinguishable at 370 and 390 pS, respectively.

Tom40 is the voltage dependent channel. In the absence of membrane potential, the reconstituted channel is completely open but closes symmetrically at positive or negative potentials. The studies on the reconstituted S. cerevisiae Tom 40 showed that in the presence of low membrane potential the pre-sequence peptide selectively bound to Tom 40 and thereby altered the gating of the channel but was rapidly translocated through the channel when driven by higher voltage [40]. For purified and reconstituted S. cerevisiae TOM complex, the maximal conductance was estimated at $740 \pm 18 \mathrm{pS}$, whereas the same estimate in the outer membrane vesicles was $760 \pm 12 \mathrm{pS}$. In general, the maximal conductance of the S. cerevisiae or N. crassa TOM complexes were 2-fold higher than the total conductance of renatured Tom 40 alone. The maximal conductance channel was $370 \pm 8 \mathrm{pS}$ for $S$. cerevisiae Tom 40 and $390 \pm 10 \mathrm{pS}$ for N. crassa Tom 40 at $250 \mathrm{mM} \mathrm{KCl}$. Thus, the channel properties of purified Tom 40 are lower than those of the TOM complex [58]. Interestingly, in the case of the $A$. castellanii and $D$. discoideum TOM complexes, channel conductance activities were estimated at 2.5 and $2.3 \mathrm{nS}$, respectively, in $1 \mathrm{M} \mathrm{KCl}$ [59]. After extrapolation (625 pS and $575 \mathrm{nS}$ respectively in $250 \mathrm{mM} \mathrm{KCl}$ ), this result is in agreement with the data obtained for $S$. cerevisiae and N. crassa. The data for N. crassa [60] correspond well to the conductance states for C. glabrata, where different truncated forms of purified Tom 40 were studied in planar lipid bilayers ( 125-500 pS in $250 \mathrm{mM} \mathrm{KCl}$, described by [57] (Table 1). The reconstituted version of C.glabrata Tom 40 forms provided a better understanding of the channel flickering phenomena observed during a study of $S$. cerevisiae, N. crassa, A. castellanii and D. discoideum TOM complex $[58,59]$. This data indicated flickering which is typical for this kind of the outer membrane channels.

The channel conductance was measured using the specific signal peptides known to be recognised by the TOM complex receptors [61]. The presence of signal peptides resulted in the channel flickering, i.e., rapid transitions from the fully open state to substates of lower conductance resulting from the channel blockade. This is a consequence of signal peptides interaction with TOM complex subunits. In a study by [58], it was shown that for the purified Tom 40 of S. cerevisiae, the signal peptide of CoxIV had to be used in a much higher concentration than in the case of the TOM complex to obtain a $50 \%$ reduction in open channel probability ( $3 \mu \mathrm{M}$ vs. $50-80 \mathrm{nM}$ ). This implies that the sensitivity of the Tom 40 channel pore is enhanced by the presence of the TOM complex subunits. The channel properties were also measured in the presence of the other recognised signal peptide. The pre-sequence peptide of the F1-ATP synthase subunit $\beta$ also induced the blockage of Tom 40 conductance in a concentration-dependent manner, which indicates a direct interaction of this peptide with the Tom 40 channel pore. Similarly, in a study of the A. castellanii and D. discoideum TOM complexes, a signal peptide of subunit 9 of ATP synthase also blocked the purified TOM complex in a concentration-dependent manner [59]. Additionally, the results obtained for the TOM complex revealed that the binding sites for the incoming precursor proteins had a presequence recognised by the TOM complex subunits, which was not present in purified Tom40. Notably, data on the individual TOM complex receptors revealed relatively low affinities (high KD) for the pre-sequences [40,62], while high-affinity binding of the pre-sequences was observed for the TOM complex [61]. Thus, data on the 
TOM complex and purified Tom 40 alone uncovered the roles of the TOM complex subunits in the regulation of Tom 40 channel activity.

It should be mentioned that the means of protein preparation for the studies on Tom 40 and other described in this review protein channels, as well as the applied methods as planar lipid bilayer membranes and patch clump could greatly influence the determined channel properties. Thus, combining electrophysiological data with structural data provide reasonable background for putative modulation. However, this always would need verification under cellular conditions.

Table 1. Characteristics of the mitochondrial outer membrane channels based on reconstitution studies *.

\begin{tabular}{|c|c|c|c|c|c|c|c|c|}
\hline $\begin{array}{l}\text { Protein } \\
\text { Name }\end{array}$ & Conductance $* *$ & $\begin{array}{l}\text { Reversal } \\
\text { Potential } \\
(\mathrm{mV})^{* * *}\end{array}$ & $P_{K^{+}} / P_{C l}^{-}$ & $\begin{array}{l}\text { Studied } \\
\text { Organism }\end{array}$ & $\begin{array}{l}\text { Constitutively } \\
\text { Open }\end{array}$ & $\begin{array}{c}\text { Molecules } \\
\text { Transported } \\
\text { across Channel }\end{array}$ & $\begin{array}{c}\text { Channel } \\
\text { Activity } \\
\text { Modulators }\end{array}$ & References \\
\hline \multirow{5}{*}{ Tom 40} & $370 \pm 8 \mathrm{pS}^{\mathrm{a}}$ & $40^{\mathrm{a}}$ & $8^{a}$ & S. cerevisiae ${ }^{\mathrm{a}}$ & \multirow[t]{2}{*}{ Yes } & $\begin{array}{l}\text { Mitochondria } \\
\text { proteins }^{\mathrm{c}} \\
\text { RNA }^{\mathrm{d}} \\
\text { Pink 1 }\end{array}$ & \multirow[t]{2}{*}{$\begin{array}{c}\mathrm{PC}^{\mathrm{i}} \\
\alpha-\text { Syn }^{\mathrm{j}}\end{array}$} & \multirow{5}{*}{$\begin{array}{c}{[58]^{\mathrm{a}}} \\
{[59]^{\mathrm{b}}} \\
{[6]^{\mathrm{c}}} \\
{[63]^{\mathrm{d}}} \\
{[64]^{\mathrm{e}}} \\
{[65]^{\mathrm{f}}} \\
{[66,67]^{\mathrm{g}}} \\
{[68]^{\mathrm{h}}} \\
{[69]^{\mathrm{h}}} \\
{[58]^{\mathrm{i}}} \\
{[70]^{\mathrm{j}}}\end{array}$} \\
\hline & $390 \pm 10 \mathrm{pS}^{\mathrm{a}}$ & & & N. crassa ${ }^{\text {a }}$ & & $A \beta^{f}$ & & \\
\hline & $\begin{array}{l}\text { TOM complex: } \\
740 \pm 18 \mathrm{pS} \\
\text { (purified } \\
\text { complex) }^{\mathrm{a}} \\
760 \pm 12 \mathrm{pS} \\
\text { (complex in }^{\text {OMVs) }}{ }^{\mathrm{a}} \\
\end{array}$ & & & S. cerevisiae ${ }^{\mathrm{a}}$ & \multirow[t]{3}{*}{ Yes } & \multirow[t]{3}{*}{$\begin{array}{l}\text { TOM complex: } \\
\text { RNA g } \\
\text { Metabolites }{ }^{\mathrm{h}}\end{array}$} & \multirow[t]{3}{*}{$\begin{array}{l}\text { signal peptides } \\
\text { of: CoxIV a } \\
\text { preSu9 }^{a, b}\end{array}$} & \\
\hline & $\begin{array}{c}625 \text { npS (purified } \\
\text { complex) }^{b}\end{array}$ & & & A. castellanii ${ }^{\mathrm{b}}$ & & & & \\
\hline & $\begin{array}{l}575 \text { pS (purified } \\
\text { complex) }^{b}\end{array}$ & & & D. discoideum ${ }^{\mathrm{b}}$ & & & & \\
\hline $\begin{array}{l}\text { Tob55/ } \\
\text { Sam50 }\end{array}$ & $640 \mathrm{pS}^{\mathrm{k}}$ & $30^{k}$ & $4^{\mathrm{k}}$ & S. cerevisiae ${ }^{\mathrm{k}}$ & Yes & $\begin{array}{c}\beta \text { barrel proteins }{ }^{1} \\
\text { Granzymes (a and } \\
\text { b) }{ }^{\mathrm{m}} \\
\text { Caspase- }^{\mathrm{m}} \\
\text { Suggested: } \\
\text { metabolites }^{\mathrm{n}}\end{array}$ & Unknown & $\begin{array}{c}{[71]^{\mathrm{k}}} \\
{[30]^{1}} \\
{[72]^{\mathrm{m}}} \\
{[73,74]^{\mathrm{n}}}\end{array}$ \\
\hline Mdm10 & $480 \mathrm{pS}^{\circ}$ & $21.5^{\circ}$ & $2.8^{\circ}$ & S. cerevisiae $^{\mathrm{o}}$ & Yes & Unknown & Tom22 ${ }^{\circ}$ & {$[14]^{\circ}$} \\
\hline Mim1 & $580 \mathrm{pS}^{\mathrm{p}}$ & $53^{p}$ & $23.5^{\mathrm{P}}$ & S. cerevisiae ${ }^{\mathrm{p}}$ & $\mathrm{N} / \mathrm{D}$ & $\begin{array}{c}\alpha \text { helical outer } \\
\text { membrane proteins }\end{array}$ & $\operatorname{Mim} 2 \mathrm{p}$ & $\begin{array}{l}{[4]^{\mathrm{p}}} \\
{[12]^{\mathrm{r}}}\end{array}$ \\
\hline MAC & $1500-5000 \mathrm{pS}^{\mathrm{s}}$ & $\begin{array}{c}\text { voltage- } \\
\text { independent }\end{array}$ & $3^{t}$ & Mammalian $^{\mathrm{s}}$ & No & $\begin{array}{c}\text { apoptotic cofactors } \\
\text { e.g.,: } \\
\text { Cyt c } \\
\text { Smac/DIABLO } \\
\text { AIF }^{\mathrm{s}}\end{array}$ & $\begin{array}{c}\text { Bcl-2 }^{\mathrm{s}} \\
\text { Bcl-xL }^{\mathrm{s}} \\
\text { Dibucaine } \\
\text { Trifluoperazine }^{\mathrm{s}} \\
\text { Propranolol (and } \\
\text { its derivatives) }^{\mathrm{s}}\end{array}$ & $\begin{array}{l}{[75]^{\mathrm{s}}} \\
{[76]^{\mathrm{t}}}\end{array}$ \\
\hline OMC7 & $570 \mathrm{pS} p$ & $-12.5 \mathrm{p}$ & $0.55^{\mathrm{P}}$ & S. cerevisiae ${ }^{p}$ & $\mathrm{~N} / \mathrm{D}$ & $\begin{array}{l}\text { Suggested: } \\
\text { RNA and/or } \\
\text { metabolites }\end{array}$ & Unknown & {$[4]^{\mathrm{p}}$} \\
\hline OMC8 & $550 \mathrm{pS}^{\mathrm{p}}$ & $-15.5^{p}$ & $0.48^{\mathrm{p}}$ & S. cerevisiae ${ }^{\mathrm{p}}$ & $\mathrm{N} / \mathrm{D}$ & $\begin{array}{l}\text { Suggested: } \\
\text { RNA and/or } \\
\text { metabolites }\end{array}$ & Unknown & {$[4]^{p}$} \\
\hline Ayr1 & $1470 \mathrm{pS}^{\mathrm{P}}$ & $30^{p}$ & $4.5^{\mathrm{P}}$ & S. cerevisiae $\mathrm{p}$ & $\mathrm{N} / \mathrm{D}$ & Suggested: proteins & $\mathrm{NADPH}^{\mathrm{r}}$ & {$[4]^{p}$} \\
\hline
\end{tabular}

* Channels are listed in the order in which they appear in the text. Abbreviations: PC-Phosphatidylcholine; $\alpha$-Syn- $\alpha$-synuclein; A $\beta$ amyloid $\beta$ peptide; Pink 1-PTEN-induced kinase 1, cyt c-cytochrome c, AIF-Apoptosis Inducing Factor. References are listed using letter designations $(\mathrm{a}-\mathrm{t})$, with each letter also being assigned to the data contained in a given publication. ${ }^{* *}$ Study performed in $250 \mathrm{mM}$ $\mathrm{KCl}$ (by planar lipid bilayer membranes), with exception of MAC channel: $150 \mathrm{mM} \mathrm{KCl}$ (study performed by patch clump). ${ }^{* *}$ Study performed in $250 \mathrm{mM} / 20 \mathrm{mM} \mathrm{KCl}$ (cis/trans) gradient.

\subsection{Tob55/Sam50 Channel}

Tob55/Sam50 protein (also known as Omp85) is a member of the Omp85 family of $\beta$-barrel-channels typical of the outer membranes of Gram-negative bacteria, mitochondria and chloroplasts $[25,45,77]$. The copy number of Tob55/Sam50 proteins in yeasts is estimated at $\sim 1500$ copies per cell $[3,46]$. The Tob55/Sam50 channel is composed of a 16stranded transmembrane $\beta$-barrel with a single polypeptide-transport-associated (POTRA) domain extending into the IMS. The POTRA domain is an N-terminal domain consisting of 
$\sim 100$ amino acids involved in the recognition and transfer of $\beta$-barrel forming precursors from the IMS via small Tim9 and Tim10 to the TOB/SAM complex [8-11].

The TOB/SAM complex was also suggested to be involved in apoptosis [72]. An important study on yeast and human cells conducted by [72] revealed that Tob55/Sam50 was required for the transport of granzymes ( $a$ and $b$ ) and caspase- 3 to cross the outer membrane. Granzymes are serine proteases that trigger cell death in a caspase-dependent and independent manner [78,79]. It was also shown that Tob55/Sam50 was sufficient for active caspase-3 to enter the mitochondria to induce cell death. Moreover, the depletion of Tob55/Sam50 caused cells to become more resistant to cell death. Thus, Tob55/Sam50 is engaged in a wider range of imported substrates than previously thought (Table 1).

The TOB/SAM complex remains in dynamic interactions with other complexes, including TOM [80,81], MICOS (e.g., [82]) and ERMES (shared Mdm10 subunit) [83]. The TOM complex binding site is based on the interaction between Tom22 and Tob37 [29,81] and on the interaction between Tom 5 and Tom22. It was found that a small fraction of Tom5 being associated with a TOB/SAM complex promotes the folding of Tom 40 during its import to the outer membrane $[80,84]$. The interaction of the TOB/SAM complex with the MICOS complex is based on Mic60/mitofilin $[36,85,86]$ and results in the regulation of cristae morphology, mitochondrial shape and respiratory chain complexes' assembly [85-87]. It has been shown that the TOB/SAM complex subunits exist in a large protein complex with Mic60/mitofilin, other Mic proteins (i.e., Mic10, Mic12, Mic19, Mic23, Mic25 and Mic 27) and CHCHD3 to create the so-called large mitochondrial IMS bridging (MIB) complex $[85,86,88]$. The MIB complex also likely contains the homolog metaxin-3 the DnaJC11 protein [89]. The depletion of Tob55/Sam50 in human cells resulted in the loss of the crista junction, which highlights its crucial function in crista formation [89]. The interaction of TOB/SAM with ERMES is mediated by Mdm10, which is considered a subunit of both of these complexes [82,90,91].

The Tob55/Sam50 channel has an inner diameter of approximately 7-8 nm (outer diameter: $\sim 15 \mathrm{~nm}$, central cavity: $\sim 4-5 \mathrm{~nm}$ ) [3,11]. A recent study on the $S$. cerevisiae TOB/SAM complex performed by electron microscopy at a resolution of $0.28-0.32 \mathrm{~nm}$ resulted in the description of two different forms of the TOB/SAM complex [92]. The TOB/SAM complex forms a dimer based on two different Tob55/Sam50 isoforms: Tob55/Sam50a and Tob55/Sam50b. Tob55/Sam50a is responsible for channel formation, while isoform $\mathrm{b}$ is responsible for releasing incoming precursor proteins from the channel [92]. The $S$. cerevisiae Tob55/Sam50 channel was studied in planar lipid bilayers, which revealed that it displayed a conductance of $640 \mathrm{pS}$ at $250 \mathrm{mM} \mathrm{KCl} \mathrm{[71].} \mathrm{This} \mathrm{result} \mathrm{is} \mathrm{in} \mathrm{agreement} \mathrm{with}$ data obtained by [8] where Tob55/Sam50 showed a channel activity level of $3.75 \mathrm{nS}$ in 1M $\mathrm{KCl}$ what after extrapolation correspond to $925 \mathrm{pS}$ in $250 \mathrm{mM} \mathrm{KCl} \mathrm{Tob55/Sam50} \mathrm{has} \mathrm{a}$ preference for cations $\left(P_{K^{+}} / P_{C l}{ }^{-}=4: 1\right)$ and a reversal potential of $30 \mathrm{mV}$ [8,71]. At voltages greater than $\pm 70 \mathrm{mV}$, the channel formed by Tob55/Sam50 is partially closed, which clearly distinguishes this channel from the VDAC channel measured by the same technique as planar lipid bilayers [93]. It has also been shown that the channel is mediated by a precursor protein $\beta$-signal that causes the displacement of the endogenous carboxy-terminal $\beta$-signal of the Tob55/Sam50 channel [94]. $\beta$-signal is localised at the $C$-terminal part of $\beta$-barrel precursor proteins and is highly conservative among bacteria, mitochondria and chloroplasts $[71,94]$. $\beta$-signal was shown to interact with Tob55/Sam 50 channel and bind precisely at its $\beta$-strand 1 . In doing so, it replaces $\beta$-strand 16 (endogenous Tob55/Sam 50 $\beta$-signal). This opens the channel's lateral gate between $\beta$-strand 1 and $\beta$-strand 16 [94]. From this point, the remaining precursor proteins are inserted to gradually gain $\beta$ structures. At the end of this process, matured protein is released into the outer membrane of the mitochondria $[29,94,95]$ (Table 1$)$.

\subsection{Mdm10 Channel}

Mdm10 has no sequence homologs in bacteria and is not present in higher eukaryotes [10]. In S. cerevisiae, its molecular weight is $56 \mathrm{kDa}$ and the copy number is estimated at $\sim 500$ 
copies per cell [46]. Mdm10 was found together with Mdm12, Mdm34 and Mmm1 as a part of a complex responsible for the maintenance of mitochondrial morphology and distribution [96]. Mdm10 is involved in lipid biosynthesis and the tethering of the endoplasmic reticulum (ER) with mitochondria [83]. The resulting connection between these organelles is called the ERMES complex [97]. In addition, being a part of the ERMES complex, Mdm10 protein was reported to bind to the TOB/SAM complex and influence $\beta$-barrel protein import into the mitochondrial outer membrane [83,90,91]. After being trans-ported through the TOB/SAM complex into the TOM, Mdm10 is involved in the late assembly of the TOM complex by interacting with the TOB/SAM complex in the process of proper Tom 40 protein assembly $[83,90,98]$. This step involves the association of Tom 40 with Tom 22 and small Tom proteins. This interaction between Mdm10 and TOB/SAM is regulated by Tom7 protein, which stimulates the release of Mdm10 from the TOB/SAM complex $[3,28,98,99]$.

After incorporation into liposomes and planar lipid bilayers, the expressed and purified S. cerevisiae Mdm10 exhibits channel activity with a main conductance of $480 \mathrm{pS}$ at $250 \mathrm{mM} \mathrm{KCl}$ and has a preference for cation selectivity $\left(P_{K^{+}} / P_{C l}{ }^{-}=2.8: 1\right.$; reversal potential: $21.5 \mathrm{mV}$ ). Moreover, three independently gated pores have been reported [14]. Additionally, the presence of Tom22 precursor increases Mdm10 conductance to $550 \mathrm{pS}$ at $250 \mathrm{mM} \mathrm{KCl}$ while also increasing the number of independently gated pores from three to four. This indicates the possible function of Mdm10 in the import of Tom22 protein [4,14].

\subsection{Mim1 Channel}

Mim1, also known as Tom13, plays a role in the import of $\alpha$-helical outer membrane proteins such as Tom70 and Tom20 [12]. This protein forms a channel composed of the $\mathrm{N}$-terminal domain exposed to the cytosol, central putative transmembrane segment (TMS) and C-terminal domain exposed to the IMS [12,13]. Mim1 is involved in the import of small Tom proteins and indirectly influences proper Tom 40 membrane insertion $[100,101]$ because the N-terminal domain of Mim1 and Tob37/Sam37 combined regulate the release of Tom40 protein from TOB/SAM [13,100]. Mim1 is also crucial for the proper insertion of Tom70 and Tom20, which, in the case of the latter, requires the homo-oligomerisation of Mim1 proteins via its transmembrane domain (TMS) [12]. It has also been shown that the precursors of multi-spanning $\alpha$-helical proteins directly interact with Mim1, which cooperates with the Tom70 receptor for protein insertion into the outer mitochondrial membrane [101]. Moreover, Mim1 regulates the binding and insertion of mitochondrial fusion and the transport protein Ugo1 [102] while promoting the import of UBX domaincontaining protein 2 (Ubx2), which is the TOM complex-associated protein suspected to remove mitochondrial precursor proteins that become stuck in the import channel [103].

The S. cerevisiae Mim1, expressed in E. coli and then purified and renatured, was studied in planar lipid bilayer. A channel conductance of $580 \mathrm{pS}$ was calculated at $250 \mathrm{mM}$ $\mathrm{KCl}$ and a closing tendency due to high positive and negative voltage was observed. This study showed cation selectivity $\left(P_{K^{+}} / P_{C l}{ }^{-}=23.5: 1\right)$ and a reversal potential of $53 \mathrm{mV}$ [4]. The channel activity was modulated by specific anti-Mim1 antibodies. The same channel properties were obtained for S. cerevisiae Mim1 expressed in wheat germ lysate [4]. Modulation of the Mim1 channel was also observed after adding purified Mim2, which did not reveal channel activity. The channel properties of Mim1 determined in the presence of Mim2 included a reduced maximal current, decreased reversal potential of $48 \mathrm{mV}$ and reduced cation selectivity $P_{K}{ }^{+} / P_{C l}{ }^{-}$of 11:1. Thus, Mim1 is a channel of cation preference for the positively charged precursor proteins modulated by the Mim2 protein [4].

\subsection{Mitochondrial Apoptosis-Induced Channel (MAC)}

MAC is the outer membrane large channel known as an early marker of the onset of apoptosis. It participates in release of proteins normally constrained within the intermembrane space, such as cytochrome c, second mitochondria-derived activator of caspases (Smac)/Direct inhibitor of apoptosis-binding protein with low $\mathrm{pI}$ (DIABLO) or apoptosis 
induced factor (AIF) [75,104]. MAC is formed by Bax and/or Bak proteins and at least one of the proteins must be present. Bax protein is cytosolic whereas Bak is an integral protein of the outer membrane and they both stay in an inactive form until MAC formation [75,104]. The activity of MAC is significantly different from the TOM and TOB/SAM complexes. Moreover, the former are constitutive channels of the outer membrane whereas MAC activity co-occur only with apoptosis $[75,76,104]$. MAC activity is regulated by other Bcl-2 family proteins. Bcl-2 and Bcl-xL inhibit apoptosis by separating Bax and Bak. Moreover, MAC can be block by dibucaine, trifluoperazine and propranolol in a dose-dependent manner) as well as 3.6 dibromocarbazole piperazine derivatives of 2-propanol (that blocked cytochrome $\mathrm{c}$ release induced in isolated mitochondria by tBid).

By application of patch-clump, the reconstituted MAC conductance was estimated as heterogenous; i.e between $1.5-5 \mathrm{nS}(1500-5000 \mathrm{pS}$ in $150 \mathrm{mM} \mathrm{KCl})$. MAC frequently fluctuates between the fully open state and fully closed state, with a maximal single transition size of $2000 \mathrm{pS}$ in $150 \mathrm{mM} \mathrm{KCl}$ and at least three substates [75]. MAC is a voltage-independent channel and is slightly cation-selective. As it has been shown for mammalian apoptotic FL5.12 cells after interleukin 3 (IL-3) withdrawal, $P_{K}{ }^{+} / P_{C l}{ }^{-}=3: 1$. The cation selectivity is consistent with its putative role in releasing cationic proteins such as cytochrome $c$ [75]. At high conductance state MAC is permeable dextran of molecular weight in the range of 10 to $17 \mathrm{kDa}$, but not in the range of 45 to $71 \mathrm{kDa}$. Based on the polymer exclusion method, MAC pore diameters were estimated in the range of 2.9 to $7.6 \mathrm{~nm}[75,76]$.

\section{Non-Proteinaceous Molecules Transported by Protein Import Channels}

\subsection{Transport of RNA}

RNA import into mitochondria has been shown for many different groups of eukaryotic organisms, including plants, mammals, yeast S. cerevisiae and protozoans. Notably, it is assumed that this phenomenon is universal for all eukaryotes. It has also been shown that mitochondria can import diverse types of RNA molecules, which suggests the existence of an extrinsic RNA importome [105]. The latter includes transfer RNAs (tRNAs), ribosomal RNAs (rRNAs), microRNAs (miRNAs) and long non-coding RNAs (lncRNAs) (for a review on this topic, see [105-107]). RNA import and the imported RNA molecules' contribution to gene expression are considered essential for mitochondrial function (e.g., [108]). The majority of the studied imported RNA molecules are tRNAs (e.g., $[109,110])$ since their import can be clearly explained as a compensation for tRNA encoding genes not being present in the mitochondrial genome (mtDNA). This applies to plants lacking a few tRNA encoding genes in mtDNA (e.g., [111]) as well as protozoans lacking a distinct part or complete set of tRNA coding genes in mtDNA (e.g., Tetrahymena thermophila, Trypanosoma brucei and Leishmania tarentolae [112-114]). Moreover, tRNA import from the cytosol can be observed in the presence of all necessary tRNA genes in mtDNA and is regarded as an important mechanism in stress response [105,115].

Available data indicates that routes for RNA import into the mitochondria may overlap with mitochondrial protein import channels since some components of the TOM and TIM complexes may contribute to translocation across mitochondrial membranes. In the case of the mitochondrial outer membrane, translocation is purportedly mediated by Tom40; however, an important role is also assigned to relevant VDAC paralogs. In plant mitochondria, Tom 40 and Tom 20 likely participate in the fixation of RNA molecules at the surface of mitochondria $[63,64]$, while Tom 40 is also suggested to partially contribute to translocation in yeast and mammalian mitochondria $[105,109,110,116,117]$. In the case of African trypanosomes (represented by T. brucei), the Tom 40 orthologue ATOM40 (atypical TOM, e.g., [118]), as well as Tom22 orthologues ATOM14 and two additional ATOM subunits (ATOM11 and 12), have been shown to perform RNA molecule translocation across the mitochondrial outer membrane $[63,119]$. While the proteins involved in RNA molecule translocation across the inner mitochondrial membrane remain largely unknown, data available for yeast and T. brucei point to the important contribution of TIM complexes. 
In the case of yeast mitochondria, TIM23 is suggested as the translocation pathway due to the putative involvement of Tim44 (subunits of the TiM23 complex) [105,116,120]. For T. brucei, the Tim 22 orthologue TbTim17 (subunit of the TIM22 complex) has been shown to participate in translocation [120]. For translocation, the latter requires some of the other subunits of the non-canonical, singular TIM complex [121] (i.e., TbTim42, Tb-Tim62 and putative acyl-CoA dehydrogenase homologue (ACAD) [122].

The mechanisms involved in the import of RNA molecules into mitochondria are still not completely understood and seem to differ between organisms with different phylogenetic lineages and RNA molecule types. Although the transport of molecules across mitochondrial membranes is ATP-dependent and requires the presence of the inner membrane potential and relevant translocating proteins, differences exist in terms of selective import signals and the interacting proteins participating in redirection to the mitochondrial surface (e.g., $[105,107,110])$. In the case of imported tRNA molecules, the participating proteins may involve aminoacyl-tRNA synthetases in plants and yeast (e.g., [115,123], respectively), cytosolic translation elongation factor eEF1 $\alpha$ in T. brucei [124] and glycolytic enzyme enolase in yeast [125]. It is also suggested that mitochondriatargeted proteins may be common elements participating in the redirection of different RNA molecules to mitochondria and their translocation across membranes (e.g., [105]). However, it is also suggested that RNA molecules may be translocated by Tom 40 without protein assistance [63]. There is also the possible contribution of mitochondrial IMS proteins, which could function as intramitochondrial RNA import factors, as proposed for polynucleotide phosphorylase (PNPase) in human mitochondria (e.g., [105]).

\subsection{Transport of Metabolites}

It is well known that the universal pathway for metabolite transport across the outer mitochondrial membrane is formed by the VDAC, which may be formed by different VDAC paralogs (e.g., [126-130]). The molecular mass cut-off for the transported molecules is assumed to be about $4 \mathrm{kDa}$ although the limit could be decreased when VDAC switches to lower conducting substates featuring less anion selectivity [131]. Nevertheless, VDAC is considered to be the major transport pathway for compounds as diverse as inorganic ions (e.g., $\mathrm{K}^{+}, \mathrm{Na}^{+}$and $\mathrm{Cl}^{-}$), metabolites of different size and charge (e.g., big anions as ATP, AMP and glutamate and small anions as superoxide anion as well as big cations as NADH and acetylocholine) and large macromolecules such as tRNA (e.g., [128,132,133]). However, for yeast $S$. cerevisiae mitochondria under the condition of the dominant VDAC para$\log (\mathrm{yVDAC})$ limited permeability or encoding gene deletion, metabolite transport across the mitochondrial outer membrane may be supported by the TOM complex $[68,69,134]$. This assumption was initially based on observation that in the absence of yVDAC1, NADH, ADP and CATR (carboxyatractylate) displayed limited access into the mitochondrial intermembrane space and the observed limitations depended on charge and size of these molecules (the highest for CATR being big anion of molecular weight higher than ADP and the lowest for NADH being big cation of molecular weight slightly smaller than CATR). Moreover, the limitations were weakened by the presence of $\mathrm{Mg}^{2+}$ that together implies involvement of cation selective channel of lower conductance that yVDAC1 [134]. This in turn correlates with the electrophysiological characteristic of the TOM complex channel (see Section 3.1 for details).

Later, it has been proven that blockage of the TOM complex by an imported protein decreases external reduced nicotinamide adenine dinucleoide (NADH) access to the inner membrane, which limits imported protein translocation by the TOM complex and increases competition in the absence of functional yVDAC1. Moreover, it has been observed that blocking the TOM complex with an imported protein decreased superoxide anion $\left(\mathrm{O}_{2}{ }^{\bullet-}\right)$ release from mitochondria, particularly in the absence of functional yVDAC1 [135]. Notably, yeast mitochondria contain two VDAC paralogs (i.e., yVDAC1 and yVDAC2 [136,137]), both of which can form channels of comparable electrophysiological characteristics [130], but differ in their expression levels and (likely) substrate selectivity [138]. These postu- 
lated differences coincide with a yVDAC2 contribution to the global permeability of the mitochondrial outer membrane that has remained undetected to date $[4,139]$. While yVDAC2 encoding gene deletion also results in competition between imported proteins and external NADH for access to the yeast mitochondria inner membrane, this competition is distinctly less pronounced than in the absence of functional yVDAC1 [68]. This observation contributes to solving the unresolved issue of yVDAC2 function.

One of the regulatory aspects concerning TOM complex involvement in metabolite transport is the expression level of its subunits. It has been reported that the expression level increases in the absence of yVDAC1 or yVDAC2, with the latter increase being less pronounced [68,73]. The upregulation of TOM complex subunits may result from increased transcription as well as the stability and/or translation of proper mRNAs [140]. Interestingly, this upregulation appears to be mediated by the cytosol reduction-oxidation (redox) state change in the absence of $\mathrm{yDDAC} 1$ or $\mathrm{yDDAC} 2$ and during yeast cell growth $[73,74]$. Moreover, redox state-dependent upregulation was also observed for Tob55/Sam50, which implicates TOB/SAM complex involvement in metabolite transport [73,74,139]; however, functional data to support this involvement remain missing.

\subsection{Ayr1 and OMC7 and OMC8: Mitochondrial Outer Membrane Channels for Unknown Molecules}

In the mitochondrial outer membrane, three channels of unknown function have been identified. These include a cation-selective channel formed by Ayr1 and two channels of anion selectivity formed by OMC7 and OMC8 [4]. S. cerevisiae Ayr1 (1-acyldihydroxyacetonephosphate reductase) is a $33 \mathrm{kD}$ protein containing a conserved nucleotide-binding motif (TGX3GXG) that is localised in the ER [141,142]. It was suggested that this could be part of the contact sites between the ER and mitochondria [143]. This protein has also been suggested to participate in cell wall biogenesis and lipid metabolism [144]; however, its true function remains unexplained.

Ayr1 reconstituted in liposomes in planar lipid bilayer membrane revealed a main conductance of $1.47 \mathrm{nS}$ in $1 \mathrm{M} \mathrm{KCl}$ ( $367 \mathrm{pS}$ at $250 \mathrm{~m} \mathrm{M} \mathrm{KCl}$ after extrapolation) in the fully open state. Additionally, three partially open states with a lower conductance of $\cong 490 \mathrm{pS}$ at $250 \mathrm{mM} \mathrm{KCl}$ and a reversal potential of $30 \mathrm{mV}$ were observed. It has also been shown that the channel, as a monomer, displays cation selectivity $\left(P_{K^{+}} / P_{C l}{ }^{-}=4.5: 1\right)$ that can be modulated by NADPH, which increases the reversal potential to $43 \mathrm{mV}$ and cation selectivity ratio $P_{K}{ }^{+} / P_{C l}{ }^{-}$to 10:1 [4]. The observed cation selectivity of the Ayr1 channel might suggests its contribution to protein import. The presented parameters of the Ayr1 could be consistent with a localization of Ayr1 in mitochondrial outer membrane and ER fractions, as being arranged in contact sites between ER and mitochondria.

In contrast, OMC7 and OMC8 were described as anion-selective channels of similar conductance (550 and 570 pS, respectively, at $250 \mathrm{mM} \mathrm{KCl}$ ) (Table 1). In light of its anion selectivity, these channels could not be suggested as being engaged in the interaction with positively charged precursor protein; however, its contribution to nucleic acid and metabolite transport within and outside of the mitochondria are worthy of further study.

\section{Conclusions and Perspectives}

The mitochondrial outer membrane selectively communicates with the cytosol environment via protein channels for a wide variety of molecules that must be delivered into the mitochondria and/or released from the mitochondria. Moreover, these channels display high flexibility in their specificity, as illustrated by their ability to transport different types of molecules. Undoubtedly, these results highlight many implications for the channel modulation that might affect mitochondrial protein turnover as well as transport of different small molecules including crucial metabolites as ATP, ADP, substrates of the respiratory chain and superoxide anion, as well as drugs as granzymes. This in turn might be beneficial for treatment of mitochondria-linked diseases mediated by the outer membrane permeability impairment as cancer [75] as well as by incorrect intramitochondrial processes as neurodegenerative disorders including Parkinson and Alzheimer diseases. 
Author Contributions: Conceptualization: M.W.; Writing: M.M., H.K. and M.W.; Preparing Figure and Table: M.M. Editing: M.W.; formatting: M.M. All authors have read and agreed to the published version of the manuscript.

Funding: This research was funded by the National Science Center (Poland) project (grant no. 2012/05/ N/NZ3/00293 and the "KNOW RNA Research Center in Poznan" (grant no. 01/KNOW2/2014).

Institutional Review Board Statement: Not applicable.

Informed Consent Statement: Not applicable.

Acknowledgments: We would like to thank the Dean of the Faculty of Biology for the financial support.

Conflicts of Interest: The authors declare no conflict of interest.

\section{References}

1. Kutik, S.; Guiard, B.; Meyer, H.E.; Wiedemann, N.; Pfanner, N. Cooperation of translocase complexes in mitochondrial protein import. J. Cell Bio. 2007, 179, 585-591. [CrossRef] [PubMed]

2. Wiedemann, N.; Pfanner, N. Mitochondrial machineries for protein import and assembly. Annu. Rev. Biochem. 2017, 86, 685-714. [CrossRef] [PubMed]

3. Pfanner, N.; Warscheid, B.; Wiedemann, N. Mitochondrial proteins: From biogenesis to functional networks. Nat. Rev. Mol. Cell Biol. 2019, 20, 267-284. [CrossRef] [PubMed]

4. $\quad$ Kruger, V.; Becker, T.; Becker, L.; Montilla-Martinez, M.; Ellenrieder, L.; Vögtle, F.N.; Meyer, H.E.; Ryan, M.T.; Wiedemann, N.; Warscheid, B.; et al. Identification of new channels by systematic analysis of the mitochondrial outer membrane. J. Cell Biol. 2017, 216, 3485-3495. [CrossRef] [PubMed]

5. Checchetto, V.; Szabo, I. Novel channels of the outer membrane of mitochondria: Recent discoveries change our view. Bioessays 2018, 40, e1700232. [CrossRef]

6. Endo, T.; Yamano, K. Multiple pathways for mitochondrial protein trafc. Biol. Chem. 2009, 390, 723-730. [CrossRef] [PubMed]

7. Kreimendahl, S.; Rassow, J. The mitochondrial outer membrane protein Tom70-mediator in protein traffic, membrane contact sites and innate immunity. Int. J. Mol. Sci. 2020, 21, 7262. [CrossRef]

8. Paschen, S.A.; Waizenegger, T.; Stan, T.; Preuss, M.; Cyrklaff, M.; Hell, K.; Rapaport, D.; Neupert, W. Evolutionary conservation of biogenesis of $\beta$-barrel membrane proteins. Nature 2003, 426, 862-866. [CrossRef] [PubMed]

9. Habib, S.J.; Waizenegger, T.; Niewienda, A.; Paschen, S.A.; Neupert, W.; Rapaport, D. The N-terminal domain of Tob55 has a receptor-like function in the biogenesis of mitochondrial $\beta$-barrel proteins. J. Cell Biol. 2007, 176, 77-88. [CrossRef] [PubMed]

10. Zeth, K. Structure and evolution of mitochondrial outer membrane proteins of $\beta$-barrel topology. Biochim. Biophys. Acta 2010, 1797, 1292-1299. [CrossRef]

11. Misra, R. Assembly of the $\beta$-barrel outer membrane proteins in Gram-negative bacteria, mitochondria, and chloroplasts. ISRN Mol. Biol. 2012, 2012, 708203. [CrossRef]

12. Popov-Celeketic, J.; Waizenegger, T.; Rapaport, D. Mim1 functions in an oligomeric form to facilitate the integration of Tom20 into the mitochondrial outer membrane. J. Mol. Biol. 2008, 376, 671-680. [CrossRef]

13. Lueder, F.; Lithgow, T. The three domains of the mitochondrial outer membrane protein Mim1 have discrete functions in assembly of the TOM complex. FEBS Lett. 2009, 583, 1475-1480. [CrossRef]

14. Ellenrieder, L.; Opalinski, L.; Becker, L.; Kruger, V.; Mirus, O.; Straub, S.P.; Ebell, K.; Flinner, N.; Stiller, S.B.; Guiard, B.; et al. Separating mitochondrial protein assembly and endoplasmic reticulum tethering by selective coupling of Mdm10. Nat. Commun. 2016, 7, 13021. [CrossRef]

15. Chacinska, A.; Koehler, C.M.; Milenkovic, D.; Lithgow, T.; Pfanner, N. Importing mitochondrial proteins: Machineries and mechanisms. Cell 2009, 138, 628-644. [CrossRef]

16. Truscott, K.N.; Kovermann, P.; Geissler, A.; Merlin, A.; Meijer, M.; Driessen, A.J.; Rassow, J.; Pfanner, N.; Wagner, R. A presequenceand voltage-sensitive channel of the mitochondrial preprotein translocase formed by Tim23. Nat. Struct. Biol. 2001, 8, 1074-1082. [CrossRef]

17. Sirrenberg, C.; Bauer, M.F.; Guiard, B.; Neupert, W.; Brunner, M. Import of carrier proteins into the mitochondrial inner membrane mediated by Tim22. Nature 1996, 384, 582-585. [CrossRef] [PubMed]

18. Callegari, S.; Richter, F.; Chojnacka, K.; Jans, D.C.; Lorenzi, I.; Pacheu-Grau, D.; Jakobs, S.; Lenz, C.; Urlaub, H.; Dudek, J.; et al. TIM29 is a subunit of the human carrier translocase required for protein transport. FEBS Lett. 2016, 590, 4147-4158. [CrossRef]

19. Callegari, S.; Cruz-Zaragoza, L.D.; Rehling, P. From TOM to the TIM23 complex-handing over of a precursor. Biol. Chem. 2020, 401, 709-721. [CrossRef] [PubMed]

20. Chaudhuri, M.; Darden, C.; Gonzalez, F.S.; Singha, U.K.; Quinones, L.; Tripathi, A. Tim17 updates: A comprehensive review of an ancient mitochondrial protein translocator. Biomolecules 2020, 10, 1643. [CrossRef] [PubMed]

21. Neupert, W. A perspective on transport of proteins into mitochondria: A myriad of open questions. J. Mol. Biol. 2015, 427, 1135-1158. [CrossRef] [PubMed] 
22. Doan, K.N.; Ellenrieder, L.; Becker, T. Mitochondrial porin links protein biogenesis to metabolism. Curr. Genet. 2019, 65, 899-903. [CrossRef]

23. Sirrenberg, C.; Endres, M.; Folsch, H.; Stuart, R.A.; Neupert, W.; Brunner, M. Carrier protein import into mitochondria mediated by the intermembrane proteins Tim10/Mrs11 and Tim12/Mrs5. Nature 1998, 391, 912-915. [CrossRef]

24. Adam, A.; Endres, M.; Sirrenberg, C.; Lottspeich, F.; Neupert, W.; Brunner, M. Tim9, a new component of the TIM22.54 translocase in mitochondria. EMBO J. 1999, 18, 313-319. [CrossRef]

25. Kozjak, V.; Wiedemann, N.; Milenkovic, D.; Lohaus, C.; Meyer, H.E.; Guiard, B.; Meisinger, C.; Pfanner, N. An Essential role of Sam50 in the protein sorting and assembly machinery of the mitochondrial outer membrane. J. Biol. Chem. 2003, $278,49$. [CrossRef]

26. Wiedemann, N.; Kozjak, V.; Chacinska, A.; Schonfisch, B.; Rospert, S.; Ryan, M.T.; Pfanner, N.; Meisinger, C. Machinery for protein sorting and assembly in the mitochondrial outer membrane. Nature 2003, 424, 565-571. [CrossRef]

27. Waizenegger, T.; Habib, S.J.; Lech, M.; Mokranjac, D.; Paschen, S.A.; Hell, K.; Neupert, W.; Rapaport, D. Tob38, a novel essential component in the biogenesis of betabarrel proteins of mitochondria. EMBO Rep. 2004, 5, 704709. [CrossRef]

28. Klein, A.; Israel, L.; Lackey, S.W.K.; Nargang, F.E.; Imhof, A.; Baumeister, W.; Neupert, W.; Thomas, D.R. Characterization of the insertase for $\beta$-barrel proteins of the outer mitochondrial membrane. J. Cell Biol. 2012, 99, 599-611. [CrossRef] [PubMed]

29. Diederichs, K.A.; Ni, X.; Rollauer, S.E.; Botos, I.; Tan, X.; King, M.S.; Kunji, E.R.S.; Jiang, J.; Buchanan, S.K. Structural insight into mitochondrial $\beta$-barrel outer membrane protein biogenesis. Nat. Commun. 2020, 11, 3290. [CrossRef]

30. Kozjak-Pavlovic, V.; Ross, K.; Benlasfer, N.; Kimmig, S.; Karlas, A.; Rudel, T. Conserved roles of Sam50 and metaxins in VDAC biogenesis. EMBO Rep. 2007, 8, 576-582. [CrossRef] [PubMed]

31. Xiea, J.; Marusichb, M.F.; Soudac, P.; Whiteleggec, J.; Capaldi, R.A. The mitochondrial inner membrane protein Mitofilin exists as a complex with SAM50, metaxins 1 and 2, coiled-coil-helix domain-containing protein 3 and 6 and DnaJC11. FEBS Lett. 2007, 581, 3545-3549. [CrossRef]

32. Cartron, P.F.; Petit, E.; Bellot, G.; Oliver, L.; Vallette, F.M. Metaxins 1 and 2, two proteins of the mitochondrial protein sorting and assembly machinery, are essential for Bak activation during TNF alpha triggered apoptosis. Cell. Signal. 2014, 26, 1928-1934. [CrossRef]

33. Buczek, D.; Wojtkowska, M.; Suzuki, Y.; Sonobe, S.; Nishigami, Y.; Antoniewicz, M.; Kmita, H.; Makałowski, W. Protein import complexes in the mitochondrial outer membrane of Amoebozoa representatives. BMC Genom. 2016, 17, 99. [CrossRef]

34. Wojtkowska, M.; Buczek, D.; Suzuki, Y.; Shabardina, V.; Makałowski, W.; Kmita, H. The emerging picture of the mitochondrial protein import complexes of Amoebozoa supergroup. BMC Genom. 2017, 18, 997. [CrossRef]

35. Mazur, M.; Wojtkowska, M.; Skalski, M.; Słocińska, M.; Kmita, H. The TOB/SAM complex composition in mitochondria of Dictyostelium discoideum during progression from unicellularity to multicellularity. Acta Biochim. Pol. 2019, 66, 551-557. [CrossRef]

36. Kornera, C.; Barrerac, M.; Dukanovice, J.; Eydt, K.; Harner, M.; Rabla, R.; Vogelf, F.; Rapaporte, D.; Neupert, W.; Reichert, A.S. The C-terminal domain of Fcj1 is required for formation of crista junctions and interacts with the TOB/SAM complex in mitochondria. Mol. Biol. Cell 2012, 23, 2143-2155. [CrossRef]

37. Kozjak-Pavlovic, V. The MICOS complex of human mitochondria. Cell Tissue Res. 2017, 367, 83-93. [CrossRef] [PubMed]

38. Horvath, S.E.; Rampelt, H.; Oeljeklaus, S.; Warscheid, B.; van der Laan, M.; Pfanner, N. Role of membrane contact sites in protein import into mitochondria. Protein Sci. 2015, 24, 277-297. [CrossRef] [PubMed]

39. Dekker, P.J.; Martin, F.; Maarse, A.C.; Bömer, U.; Muller, H.; Guiard, B.; Meijer, M.; Rassow, J.; Pfanner, N. The Tim core complex defines the number of mitochondrial translocation contact sites and can hold arrested preproteins in the absence of matrix Hsp70-Tim44. EMBO J. 1997, 16, 5408-5419. [CrossRef] [PubMed]

40. Hill, K.; Model, K.; Ryan, M.T.; Dietmeier, K.; Martin, F.; Wagner, R.; Pfanner, N. Tom40 forms the hydrophilic channel of the mitochondrial import pore for preproteins. Nature 1998, 395, 516-521. [CrossRef] [PubMed]

41. Suzuki, H.; Okazawa, Y.; Komiya, T.; Saeki, K.; Mekada, E.; Kitada, S.; Ito, A.; Mihara, K. Characterization of rat TOM40, a central component of the preprotein translocase of the mitochondrial outer membrane. J. Biol. Chem. 2000, 275, 37930-37936. [CrossRef] [PubMed]

42. Meisinger, C.; Ryan, M.T.; Hill, K.; Model, K.; Lim, J.H.; Sickmann, A.; Müller, H.; Meyer, H.E.; Wagner, R.; Pfanner, N. Protein import channel of the outer mitochondrial membrane: A highly stable Tom40-Tom22 core structure differentially interacts with preproteins, small tom proteins, and import receptors. Mol. Cell. Biol. 2001, 21, 2337-2348. [CrossRef] [PubMed]

43. Kreimendahl, S.; Schwichtenberg, J.; Günnewig, K.; Brandherm, L.; Rassow, J. The selectivity filter of the mitochondrial protein import machinery. BMC Biol. 2020, 18, 156. [CrossRef] [PubMed]

44. Harner, M.; Neupert, W.; Deponteb, M. Lateral release of proteins from the TOM complex into the outer membrane of mitochondria. EMBO J. 2011, 30, 3232-3241. [CrossRef]

45. Wojtkowska, M.; Jakalski, M.; Pienkowska, J.R.; Stobienia, O.; Karachitos, A.; Przytycka, T.M.; Weiner, J., 3rd; Kmita, H.; Makalowski, W. Phylogenetic analysis of mitochondrial outer membrane $\beta$-barrel channels. Genome Biol. Evol. 2012, 4, 110-125. [CrossRef]

46. Morgenstern, M.; Stiller, S.B.; Lubbert, P.; Peikert, C.D.; Dannenmaier, S.; Drepper, F.; Weill, U.; Hoß, P.; Feuerstein, R.; Gebert, M.; et al. Definition of a high- confidence mitochondrial proteome at quantitative scale. Cell Rep. 2017, 19, 2836-2852. [CrossRef]

47. Ahting, U.; Thun, C.; Hegerl, R.; Typke, D.; Nargang, F.E.; Neupert, W.; Nussberger, S. The TOM core complex: The general protein import pore of the outer membrane of mitochondria. J. Cell Biol. 1999, 147, 959-968. [CrossRef] 
48. Shiota, T.; Imai, K.; Qiu, J.; Hewitt, V.L.; Tan, K.; Shen, H.H.; Sakiyama, N.; Fukasawa, Y.; Hayat, S.; Kamiya, M.; et al. Molecular architecture of the active mitochondrial protein gate. Science 2015, 349, 1544-1548. [CrossRef]

49. Model, K.; Meisinger, C.; Prinz, T.; Wiedemann, N.; Truscott, K.N.; Pfanner, N.; Ryan, M.T. Multistep assembly of the protein import channel of the mitochondrial outer membrane. Nat. Struct. Biol. 2001, 8, 361-370. [CrossRef]

50. Gold, V.A.; Brandt, T.; Cavellini, L.; Cohen, M.M.; Ieva, R.; van der Laan, M. Analysis of mitochondrial membrane protein complexes by electron cryo-tomography. Methods Mol. Biol. 2017, 1567, 315-336. [PubMed]

51. Bausewein, T.; Naveed, H.; Liang, J.; Nussberger, S. The structure of the TOM core complex in the mitochondrial outer membrane. Biol. Chem. 2020, 401, 687-697. [CrossRef]

52. Araiso, Y.; Tsutsumi, A.; Qiu, J.; Imai, K.; Shiota, T.; Song, J.; Lindau, C.; Wenz, L.S.; Sakaue, H.; Yunoki, K.; et al. Structure of the mitochondrial import gate reveals distinct preprotein paths. Nature 2019, 575, 395-401. [CrossRef]

53. Wang, W.; Chen, X.; Zhang, L.; Yi, J.; Ma, Q.; Yin, J.; Zhuo, W.; Gu, J.; Yang, M. Atomic structure of human TOM core complex. Cell Discov. 2020, 6, 1-10. [CrossRef] [PubMed]

54. Tucker, K.; Park, E. Cryo-EM structure of the mitochondrial protein-import channel TOM complex at near-atomic resolution. Nat. Struct. Mol. Biol. 2019, 26, 1158-1166. [CrossRef] [PubMed]

55. Becker, T.; Horvath, S.E.; Bottinger, L.; Gebert, N.; Daum, G.; Pfanner, N. Role of phosphatidylethanolamine in the biogenesis of mitochondrial outer membrane proteins. J. Biol. Chem. 2013, 288, 16451-16459. [CrossRef] [PubMed]

56. Bausewein, T.; Mills, D.J.; Langer, J.D.; Nitschke, B.; Nussberger, S.; Kuhlbrandt, W. Cryo-EM structure of the TOM core complex from Neurospora crassa. Cell 2017, 170, 693-700. [CrossRef]

57. Kuszak, A.J.; Jacobs, D.; Gurnev, P.A.; Shiota, T.; Louis, J.M.; Lithgow, T.; Bezrukov, S.M.; Rostovtseva, T.K.; Buchanan, S.K. Evidence of distinct channel conformations and substrate binding affinities for the mitochondrial outer membrane protein translocase pore Tom40. J. Biol. Chem. 2015, 290, 26204-26217. [CrossRef]

58. Becker, L.; Bannwarth, M.; Meisinger, C.; Hill, K.; Model, K.; Krimmer, T.; Casadio, R.; Truscott, K.N.; Schulz, G.E.; Pfanner, N.; et al. Preprotein translocase of the outer mitochondrial membrane: Reconstituted Tom 40 forms a characteristic TOM pore. J. Mol. Biol. 2005, 353, 1011-1020. [CrossRef]

59. Wojtkowska, M.; Buczek, D.; Stobienia, O.; Karachitos, A.; Antoniewicz, M.; Slocinska, M.; Makalowski, W.; Kmita, H. The TOM complex of amoebozoans: The cases of the amoeba Acanthamoeba castellanii and the slime mold Dictyostelium discoideum. Protist 2015, 166, 349-362. [CrossRef]

60. Poynor, M.; Eckert, R.; Nussberger, S. Dynamics of the preprotein translocation channel of the outer membrane of mitochondria. Biophys. J. 2008, 95, 1511-1522. [CrossRef] [PubMed]

61. Stan, T.; Ahting, U.; Dembowski, M.; Kunkele, K.P.; Nussberger, S.; Neupert, W.; Rapaport, D. Recognition of preproteins by the isolated TOM complex of mitochondria. EMBO J. 2000, 19, 4895-4902. [CrossRef]

62. Abe, Y.; Shodai, T.; Muto, T.; Mihara, K.; Torii, H.; Nishikawa, S.; Endo, T.; Kohda, D. Structural basis of presequence recognition by the mitochondrial protein import receptor Tom20. Cell 2000, 100, 551-560. [CrossRef]

63. Niemann, M.; Harsman, A.; Mani, J.; Peikert, C.D.; Oeljeklaus, S.; Warscheid, B.; Wagner, R.; Schneider, A. tRNAs and proteins use the same import channel for translocation across the mitochondrial outer membrane of trypanosomes. Proc. Natl. Acad. Sci. USA 2017, 114, E7679-E7687. [CrossRef]

64. Pickrell, A.M.; Youle, R.J. The roles of PINK1, parkin, and mitochondrial fidelity in Parkinson's disease. Neuron 2015, 85, 257-273. [CrossRef]

65. Hansson Petersen, C.A.; Alikhani, N.; Behbahani, H.; Wiehager, B.; Pavlov, P.F.; Alafuzoff, I.; Leinonen, V.; Ito, A.; Winblad, B.; Glaser, E.; et al. The amyloid beta-peptide is imported into mitochondria via the TOM import machinery and localized to mitochondrial cristae. Proc. Natl. Acad. Sci. USA 2008, 105, 13145-13150. [CrossRef]

66. Salinas, T.; Duchene, A.M.; Delage, L.; Nilsson, S.; Glaser, E.; Zaepfel, M.; Marechal-Drouard, L. The voltage-dependent anion channel, a major component of the tRNA import machinery in plant mitochondria. Proc. Natl. Acad. Sci. USA 2006, 103, 18362-18367. [CrossRef]

67. Salinas, T.; El Farouk-Ameqrane, S.; Ubrig, E.; Sauter, C.; Duchene, A.M.; Marechal-Drouard, L. Molecular basis for the differential interaction of plant mitochondrial VDAC proteins with tRNAs. Nucleic Acids Res. 2014, 42, 9937-9948. [CrossRef]

68. Antos, N.; Budzinska, M.; Kmita, H. An interplay between the TOM complex and porin isoforms in the yeast Saccharomyces cerevisiae mitochondria. FEBS Lett. 2001, 500, 12-16. [CrossRef]

69. Kmita, H.; Budzińska, M. Involvement of the TOM complex in external NADH transport into yeast mitochondria depleted of mitochondrial porin1. Biochim. Biophys. Acta 2000, 1509, 86-94. [CrossRef]

70. Di Maio, R.; Barrett, P.J.; Hoffman, E.K.; Barrett, C.W.; Zharikov, A.; Borah, A.; Hu, X.; McCoy, J.; Chu, C.T.; Burton, E.A.; et al. $\alpha$-Synuclein binds to TOM20 and inhibits mitochondrial protein import in Parkinson's disease. Sci. Transl. Med. 2016, 8, 342 ra78. [CrossRef] [PubMed]

71. Kutik, S.; Stojanovski, D.; Becker, L.; Becker, T.; Meinecke, M.; Kruger, V.; Prinz, C.; Meisinger, C.; Guiard, B.; Wagner, R.; et al. Dissecting membrane insertion of mitochondrial $\beta$-barrel proteins. Cell 2008, 132, 1011-1024. [CrossRef]

72. Chiusolo, V.; Jacquemin, G.; Bassoy, E.Y.; Vinet, L.; Liguori, L.; Walch, M.; Kozjak-Pavlovic, V.; Martinvalet, D. Granzyme B enters the mitochondria in a Sam50-, Tim22- and mtHsp70-dependent manner to induce apoptosis. Cell Death Differ. 2017, 24, 747-758. [CrossRef] 
73. Galganska, H.; Budzinska, M.; Wojtkowska, M.; Kmita, H. Redox regulation of protein expression in Saccharomyces cerevisiae mitochondria: Possible role of VDAC. Arch. Biochem. Biophys. 2008, 479, 39-45. [CrossRef]

74. Galganska, H.; Karachitos, A.; Wojtkowska, M.; Stobienia, O.; Budzinska, M.; Kmita, H. Communication between mitochondria and nucleus: Putative role for VDAC in reduction/oxidation mechanism. Biochim. Biophys. Acta 2010, 1797, 1276-1280. [CrossRef] [PubMed]

75. Dejean, L.M.; Ryu, S.Y.; Martinez-Caballero, S.; Teijido, O.; Peixoto, P.M.; Kinnally, K.W. MAC and Bcl-2 family proteins conspire in a deadly plot. Biochim. Biophys. Acta 2010, 1797, 1231-1238. [CrossRef] [PubMed]

76. Pavlov, E.V.; Priault, M.; Pietkiewicz, D.; Cheng, E.H.Y.; Antonsson, B.; Manon, S.; Korsmeyer, S.J.; Mannella, C.A.; Kinnally, K.W. A novel, high conductance channel of mitochondria linked to apoptosis in mammalian cells and Bax expression in yeast. J. Cell Biol. 2001, 155, 725-732. [CrossRef]

77. Walther, D.M.; Rapaport, D. Biogenesis of mitochondrial outer membrane proteins. Biochim. Biophys. Acta 2009, $1793,42-51$. [CrossRef]

78. Sutton, V.R.; Davis, J.E.; Cancilla, M.; Johnstone, R.W.; Ruefli, A.A.; Sedelies, K.; Browne, K.A.; Trapani, J.A. Initiation of apoptosis by granzyme B requires direct cleavage of bid, but not direct granzyme B-mediated caspase activation. J. Exp. Med. 2000, 192, 1403-1414. [CrossRef] [PubMed]

79. Goping, I.S.; Barry, M.; Liston, P.; Sawchuk, T.; Constantinescu, G.; Michalak, K.M.; Shostak, I.; Roberts, D.L.; Hunter, A.M.; Korneluk, R.; et al. Granzyme B-induced apoptosis requires both direct caspase activation and relief of caspase inhibition. Immunity 2003, 18, 355-365. [CrossRef]

80. Qiu, J.; Wenz, L.S.; Zerbes, R.M.; Oeljeklaus, S.; Bohnert, M.; Stroud, D.A.; Wirth, C.; Ellenrieder, L.; Thornton, N.; Kutik, S.; et al. Coupling of mitochondrial import and export translocases by receptor-mediated supercomplex formation. Cell 2013, 154, 596-608. [CrossRef]

81. Wenz, L.S.; Ellenrieder, L.; Qiu, J.; Bohnert, M.; Zufall, N.; van der Laan, M.; Pfanner, N.; Wiedemann, N.; Becker, T. Sam37 is crucial for formation of the mitochondrial TOM-SAM supercomplex, thereby promoting $\beta$-barrel biogenesis. J. Cell Biol. 2015, 210, 1047-1054. [CrossRef] [PubMed]

82. Rampelt, H.; Bohnert, M.; Zerbes, R.M.; Horvath, S.E.; Warscheid, B.; Pfanner, N.; van der Laan, M. Mic10, a core subunit of the mitochondrial contact site and cristae organizing system, interacts with the dimeric $\mathrm{F}_{1} \mathrm{~F}_{0}-\mathrm{ATP}$ synthase. J. Mol. Biol. 2017, 429, 1162-1170. [CrossRef] [PubMed]

83. Yamano, K.; Tanaka-Yamano, S.; Endo, T. Mdm10 as a dynamic constituent of the TOB/SAM complex directs coordinated assembly of Tom40. EMBO Rep. 2010, 11, 187-193. [CrossRef]

84. Becker, T.; Guiard, B.; Thornton, N.; Zufall, N.; Stroud, D.A.; Wiedemann, N.; Pfanner, N. Assembly of the mitochondrial protein import channel: Role of Tom5 in two-stage interaction of Tom40 with the SAM complex. Mol. Biol. Cell. 2010, 21, 3106-3113. [CrossRef]

85. Ott, C.; Ross, K.; Straub, S.; Thiede, B.; Gotz, M.; Goosmann, C.; Krischke, M.; Mueller, M.J.; Krohne, G.; Rudel, T.; et al. Sam50 functions in mitochondrial intermembrane space bridging and biogenesis of respiratory complexes. Mol. Cell. Biol. 2012, 32, 1173-1188. [CrossRef] [PubMed]

86. Ott, C.; Dorsch, E.; Fraunholz, M.; Straub, S.; Kozjak-Pavlovic, V. Detailed analysis of the human mitochondrial contact site complex indicate a hierarchy of subunits. PLOS ONE 2015, 10, e0120213. [CrossRef]

87. Ding, C.; Wu, Z.; Huang, L.; Wang, Y.; Xue, J.; Chen, S.; Deng, Z.; Wang, L.; Song, Z.; Chen, S. Mitofilin and CHCHD6 physically interact with Sam50 to sustain cristae structure. Sci. Rep. Nov. 2015, 5, 1-11. [CrossRef]

88. Huynen, M.A.; Mühlmeister, M.; Gotthardt, K.; Guerrero-Castillo, S.; Brandt, U. Evolution and structural organization of the mitochondrial contact site (MICOS) complex and the mitochondrial intermembrane space bridging (MIB) complex. Biochim. Biophys. Acta 2016, 1863, 91-101. [CrossRef]

89. Tang, J.; Zhang, K.; Dong, J.; Yan, C.; Hu, C.; Ji, H.; Chen, L.; Chen, S.; Zhao, H.; Song, Z. Sam50-Mic19-Mic60 axis determines mitochondrial cristae architecture by mediating mitochondrial outer and inner membrane contact. Cell Death Differ. 2020, 27, 146-160. [CrossRef] [PubMed]

90. Meisinger, C.; Rissler, M.; Chacinska, A.; Sanjua Szklarz, L.K.; Milenkovic, D.; Kozjak, V.; Schonfisch, B.; Lohaus, C.; Meyer, H.E.; Yaffe, M.P.; et al. The Mitochondrial Morphology Protein Mdm10 Functions in Assembly of the Preprotein Translocase of the Outer Membrane. Dev. Cell 2004, 7, 61-71. [CrossRef] [PubMed]

91. Thornton, N.; Stroud, D.A.; Milenkovic, D.; Guiard, B.; Pfanner, N.; Becker, T. Two modular forms of the mitochondrial sorting and assembly machinery are involved in biogenesis of a-helical outer membrane proteins. J. Mol. Biol. 2010, 396, 540-549. [CrossRef] [PubMed]

92. Takeda, H.; Tsutsumi, A.; Nishizawa, T.; Lindau, C.; Busto, J.V.; Wenz, L.S.; Ellenrieder, L.; Imai, K.; Straub, S.P.; Mossmann, W.; et al. Mitochondrial sorting and assembly machinery operates by $\beta$-barrel switching. Nature 2021, 590, 163-169. [CrossRef] [PubMed]

93. Blachly-Dyson, E.; Forte, M. VDAC channels. IUBMB Life 2001, 52, 113-118. [PubMed]

94. Hohr, A.I.C.; Lindau, C.; Wirth, C.; Qiu, J.; Stroud, D.A.; Kutik, S.; Guiard, B.; Hunte, C.; Becker, T.; Pfanner, N.; et al. Membrane protein insertion through a mitochondrial beta-barrel gate. Science 2018, 359, eaah6834. [CrossRef] [PubMed]

95. Lionello, S.; Marzaro, G.; Martinvalet, D. SAM50, a side door to the mitochondria: The case of cytotoxic proteases. Pharmacol. Res. 2020, 160, 105196. [CrossRef] 
96. Boldogh, I.R.; Nowakowski, D.W.; Yang, H.C.; Chung, H.; Karmon, S.; Royes, P.; Pon, L.A. A Protein Complex Containing Mdm10p, Mdm12p, and Mmm1p Links Mitochondrial Membranes and DNA to the Cytoskeleton-based Segregation Machinery. Mol. Biol. Cell 2003, 14, 4618-4627. [CrossRef]

97. Kornmann, K.; Currie, E.; Collins, S.R.; Schuldiner, M.; Nunnari, J.; Weissman, J.S.; Walter, P. An ER-mitochondria tethering complex revealed by a synthetic biology screen. Science 2009, 325, 477-481. [CrossRef]

98. Flinner, N.; Ellenrieder, L.; Stiller, S.B.; Becker, T.; Schleiff, E.; Mirus, O. Mdm10 is an ancient eukaryotic porin co-occurring with theERMES complex. Biochim. Biophys. Acta 2013, 1833, 3314-3325. [CrossRef]

99. Meisinger, C.; Wiedemann, N.; Rissler, M.; Strub, A.; Milenkovic, D.; Schonfisch, B.; Muller, H.; Kozjak, V.; Pfanner, N. Mitochondrial Protein Sorting. Differentiation of $\beta$-barrel assembly by Tom7-mediated segregation of Mdm10. J. Biol. Chem. 2006, 281, 22819-22826. [CrossRef]

100. Becker, T.; Pfannschmidt, S.; Guiard, B.; Stojanovski, D.; Milenkovic, D.; Kutik, S.; Pfanner, N.; Meisinger, C.; Wiedemann, N. Biogenesis of the mitochondrial TOM complex. Mim1 promotes insertion and assembly of signal-anchored receptors. J. Biol. Chem. 2008, 283, 120-127. [CrossRef]

101. Becker, T.; Wenz, L.S.; Kruger, V.; Lehmann, W.; Müller, J.M.; Goroncy, L.; Zufall, N.; Lithgow, T.; Guiard, B.; Chacinska, A.; et al. The mitochondrial import protein Mim1 promotes biogenesis of multispanning outer membrane proteins. J. Cell Biol. 2011, 194, 387-395. [CrossRef]

102. Papic, D.; Krumpe, K.; Dukanovic, J.; Dimmer, K.S.; Rapaport, D. Multispan mitochondrial outer membrane protein Ugo1 follows a unique Mim1-dependent import pathway. J. Cell Biol. 2011, 194, 397-405. [CrossRef]

103. Martensson, C.U.; Priesnitz, C.; Song, J.; Ellenrieder, L.; Doan, K.N.; Boos, F.; Floerchinger, A.; Zufall, N.; Oeljeklaus, S.; Warscheid, B.; et al. Mitochondrial protein translocation associated degradation. Nature 2019, 569, 679-683. [CrossRef] [PubMed]

104. Peixoto, P.M.; Lue, J.K.; Ryu, S.Y.; Wroble, B.N.; Sible, J.C.; Kinnally, K.W. Mitochondrial apoptosis-induced channel (MAC) function triggers a Bax/Bak-dependent bystander effect. Am. J. Pathol. 2011, 178, 48-54. [CrossRef] [PubMed]

105. Jeandard, D.; Smirnova, A.; Tarassov, I.; Barrey, E.; Smirnov, A.; Entelis, N. Import of non-coding RNAs into human mitochondria: A critical review and emerging approaches. Cells 2019, 8, 286. [CrossRef] [PubMed]

106. Dietrich, A.; Wallet, C.; Iqbal, R.K.; Gualberto, J.M.; Lotfi, F. Organellar non-coding RNAs: Emerging regulation mechanisms. Biochimie 2015, 117, 48-62. [CrossRef]

107. Verechshagina, N.; Nikitchina, N.; Yamada, Y.; Harashima, H.; Tanaka, M.; Orishchenko, K.; Mazunin, I. Future of human mitochondrial DNA editing technologies. Mitochondrial DNA Part A DNA Mapp. Seq. Anal. 2019, 30, 214-221. [CrossRef]

108. Kim, K.M.; Noh, J.H.; Abdelmohsen, K.; Gorospe, M. Mitochondrial noncoding RNA transport. BMB Rep. 2017, 50, 164-174. [CrossRef] [PubMed]

109. Campo, S.; Gilbert, K.B.; Carrington, J.C. Small RNA-based antiviral defense in the phytopathogenic fungus colletotrichum higginsianum. PLoS Pathog. 2016, 12, e1005640. [CrossRef]

110. Kamenski, P.; Krasheninnikov, I.; Tarassov, I. 40 Years of Studying RNA Import into Mitochondria: From Basic Mechanisms to Gene Therapy Strategies. Mol. Biol. (Mosk.) 2019, 53, 924-932. [CrossRef]

111. Ramamonjisoa, D.; Kauffmann, S.; Choisne, N.; Marechal-Drouard, L.; Green, G.; Wintz, H.; Small, I.; Dietrich, A. Structure and expression of several bean (Phaseolus vulgaris) nuclear transfer RNA genes: Relevance to the process of tRNA import into plant mitochondria. Plant Mol. Biol. 1998, 36, 613-625. [CrossRef]

112. Rusconi, C.P.; Cech, T.R. The anticodon is the signal sequence for mitochondrial import of glutamine tRNA in Tetrahymena. Genes Dev. 1996, 10, 28702880. [CrossRef]

113. Hancock, K.; Hajduk, S.L. The mitochondrial tRNAs of Trypanosoma brucei are nuclear encoded. J. Biol. Chem. 1990, 265, 19208-19215. [CrossRef]

114. Shi, X.; Chen, D.H.; Suyama, Y. A nuclear tRNA gene cluster in the protozoan Leishmania tarentolae and differential distribution of nuclear encoded tRNAs between the cytosol and mitochondria. Mol. Biochem. Parasitol. 1994, 65, 2337. [CrossRef]

115. Kamenski, P.; Smirnova, E.; Kolesnikova, O.; Krasheninnikov, I.A.; Martin, R.P.; Entelis, N.; Tarassov, I. tRNA mitochondrial import in yeast: Mapping of the import determinants in the carrier protein, the precursor of mitochondrial lysyl-tRNA synthetase. Mitochondrion 2010, 10, 284-293. [CrossRef]

116. Tarassov, I.; Entelis, N.; Martin, R.P. An intact protein translocating machinery is required f or mitochondrial import of a yeast cytoplasmic tRNA. J. Mol. Biol. 1995, 245, 315-323. [CrossRef]

117. Vyssokikh, M.Y.; Schirtz, T.; Kolesnikova, O.; Entelis, N.; Antonenko, Y.N.; Rokitskaya, T.I.; Tarassov, I. Isoform porin 2 is involved in tRNA(Lys) transport from cytosol to mitochondria in yeast. BBA Bioenerg. 2012, 1817, 124-125. [CrossRef]

118. Harsman, A.; Schneider, A. Mitochondrial protein import in trypanosomes: Expect the unexpected. Traffic 2017, 18, 96-109. [CrossRef] [PubMed]

119. Shikha, S.; Huot, J.L.; Schneider, A.; Niemann, M. tRNA import across the mitochondrial inner membrane in T. brucei requires TIM subunits but is independent of protein import. Nucleic Acids Res. 2020, 48, 12269-12281. [CrossRef] [PubMed]

120. Cosma, M.P.; Panizza, S.; Nasmyth, K. Cdk1 Triggers association of RNA polymerase to cell cycle promoters only after recruitment of the mediator by SBF. Mol. Cell 2016, 7, 1213-1220. [CrossRef]

121. Singha, U.K.; Hamilton, V.; Chaudhuri, M. Tim62, a novel mitochondrial protein in Trypanosoma brucei, is essential for assembly and stability of the TbTim17 protein complex. J. Biol. Chem. 2015, 290, 23226-23239. [CrossRef] [PubMed] 
122. Singha, U.K.; Tripathi, A.; Smith, J.T., Jr.; Quinones, L.; Saha, A.; Singha, T.; Chaudhuri, M. Novel IM-associated protein Tim54 plays a role in the mitochondrial import of internal signal-containing proteins in Trypanosoma brucei. Biol. Cell 2021, 113, 39-57. [CrossRef] [PubMed]

123. Salinas-Giege, T.; Giege, R.; Giege, P. tRNA biology in mitochondria. Int. J. Mol. Sci. 2015, 16, 4518-4559. [CrossRef] [PubMed]

124. Bouzaidi-Tiali, N.; Aeby, E.; Charriere, F.; Pusnik, M.; Schneider, A. Elongation factor 1a mediates the specificity of mitochondrial tRNA import in T. brucei. EMBO J. 2007, 26, 4302-4312. [CrossRef]

125. Entelis, N.; Brandina, I.; Kamenski, P.; Krasheninnikov, I.A.; Martin, R.P.; Tarassov, I. A glycolytic enzyme, enolase, is recruited as a cofactor of tRNA targeting toward mitochondria in Saccharomyces cerevisiae. Genes Dev. 2006, 20, 1609-1620. [CrossRef]

126. Benz, R. Permeation of hydrophilic solutes through mitochondrial outer membranes: Review on mitochondrial porins. Biochim. Biophys. Acta 1994, 1197, 167-196. [CrossRef]

127. Colombini, M. VDAC: The channel at the interface between mitochondria and the cytosol. Mol. Cell. Biochem. 2004, 256-257, 107-115. [CrossRef]

128. Shoshan-Barmatz, V.; De Pinto, V.; Zweckstetter, M.; Raviv, Z.; Keinan, N.; Arbel, N. VDAC, a multi-functional mitochondrial protein regulating cell life and death. Mol. Aspects Med. 2010, 31, 227-285. [CrossRef]

129. Mannella, C.A. VDAC-A primal perspective. Int. J. Mol. Sci. 2021, 22, 1685. [CrossRef]

130. De Pinto, V. Renaissance of VDAC: New insights on a protein family at the interface between mitochondria and cytosol biomolecules. Biomolecules 2021, 11, 107. [CrossRef]

131. Colombini, M. VDAC structure, selectivity, and dynamics. Biochim. Biophys. Acta 2012, 1818, 1457-1465. [CrossRef] [PubMed]

132. Han, D.; Antunes, F.; Canali, R.; Rettori, D.; Cadenas, E. Voltage-dependent anion channels control the release of the superoxide anion from mitochondria to cytosol. J. Biol. Chem. 2003, 278, 5557-5563. [CrossRef] [PubMed]

133. Homble, F.; Krammer, E.-M.; Prevost, M. Plant VDAC: Facts and speculations. Biochim. Biophys. Acta Biomembr. 2012, 1818, 1486-1501. [CrossRef] [PubMed]

134. Kmita, H.; Stobienia, O.; Michejda, J. The access of metabolites into yeast mitochondria in the presence and absence of the voltage dependent anion selective channel (YVDAC1). Acta Biochim. Pol. 1999, 46, 991-1000. [CrossRef]

135. Budzinska, M.; Gałgańska, H.; Karachitos, A.; Wojtkowska, M.; Kmita, H. The TOM complex is involved in the release of superoxide anion from mitochondria. J. Bioenerg. Biomembr. 2009, 41, 361-367. [CrossRef] [PubMed]

136. Blachly-Dyson, E.; Song, J.; Wolfgang, W.J.; Colombini, M.; Forte, M. Multicopy suppressors of phenotypes resulting from the absence of yeast VDAC encode a VDAC-like protein. Mol. Cell. Biol. 1997, 17, 5727-5738. [CrossRef]

137. Lee, A.C.; Xu, X.; Blachly-Dyson, E.; Forte, M.; Colombini, M. The role of yeast VDAC genes on the permeability of the mitochondrial outer membrane. J. Membr. Biol. 1998, 161, 173-181. [CrossRef]

138. Guardiani, C.; Magri, A.; Karachitos, A.; Di Rosa, M.C.; Reina, S.; Bodrenko, I.; Messina, A.; Kmita, H.; Ceccarelli, M.; De Pinto, V. yVDAC2, the second mitochondrial porin isoform of Saccharomyces cerevisiae. Biochim. Biophys. Acta Bioenerg. 2018, 1859, 270-279. [CrossRef]

139. Magri, A.; Di Rosa, M.C.; Orlandi, I.; Guarino, F.; Reina, S.; Guarnaccia, M.; Morello, G.; Spampinato, A.; Cavallaro, S.; Messina, A.; et al. Deletion of Voltage-Dependent Anion Channel 1 knocks mitochondria down triggering metabolic rewiring in yeast. Cell. Mol. Life Sci. 2020, 77, 3195-3213. [CrossRef]

140. Kmita, H.; Antos, N.; Wojtkowska, M.; Hryniewiecka, L. Processes underlying the upregulation of Tom proteins in S. cerevisiae mitochondria depleted of the VDAC channel. J. Bioenerg. Biomembr. 2004, 36, 187-193. [CrossRef]

141. Athenstaedt, K.; Daum, G. 1-Acyldihydroxyacetone-phosphate reductase (Ayr1p) of the yeast Saccharomyces cerevisiae encoded by the open reading frame YIL124w is a major component of lipid particles. J. Biol. Chem. 2000, 275, 235-240. [CrossRef] [PubMed]

142. Natter, K.; Leitner, P.; Faschinger, A.; Wolinski, H.; McCraith, S.; Fields, S.; Kohlwein, S.D. The spatial organization of lipid synthesis in the yeast Saccharomyces cerevisiae derived from large scale green fluorescent protein tagging and high resolution microscopy. Mol. Cell. Proteom. 2005, 4, 662-672. [CrossRef] [PubMed]

143. Herrera-Cruz, M.S.; Simmen, T. Over six decades of discovery and characterization of the architecture at mitochondria-associated membranes (MAMs). Adv. Exp. Med. Biol. 2017, 997, 13-31. [PubMed]

144. Ploier, B.; Scharwey, M.; Koch, B.; Schmidt, C.; Schatte, J.; Rechberger, G.; Kollroser, M.; Hermetter, A.; Daum, G. Screening for hydrolytic enzymes reveals Ayr1p as a novel triacylglycerol lipase in Saccharomyces cerevisiae. J. Biol. Chem. 2013, 288, 36061-36072. [CrossRef] 